\title{
Research
}

\section{Auditory Brainstem Response profile in speech delay patients at Universitas Gadjah Mada Academic Hospital}

\author{
Mahatma Sotya Bawono*, Ade Febrina Lestari**, Widiarahma Hapsari***, \\ Herfis Avidati***, Shinta Kusumalarna Sari*** \\ *Department of Otorhinolaryngology-Head Neck Surgery, \\ ** Department of Pediatrics, \\ $* * *$ Department of Nursing \\ Universitas Gadjah Mada Academic Hospital, Yogyakarta
}

\begin{abstract}
Background: Speech delay is one of the most common causes of developmental disorders in children and the reason for patients to be referred to the Electromedical Unit. Purpose: To find out the profile of Auditory Brainstem Response (ABR) results in pediatric patients with speech delays at the Electromedical Clinic of UGM Academic Hospital. Method: This was a retrospective descriptive observational study using secondary data, using total sampling method from January 1 to December 31,2019. The respondents were 86 children who met the inclusion and exclusion criteria. Most of the respondents were male (68.6 $\%$ ) in the age range of $2-<3$ years (45.3\%). Result: ABR examination found 68 children (79.1\%) classified as normal ABR and 18 children (31.4\%) with abnormal ABR. The highest number of respondents who obtained normal ABR results were male (42.6\%), while abnormal ABR results were higher in female (66.7\%). Respondents with normal and abnormal ABR results were mostly in the age range of $2-<3$ years, consisted of 29 children (42.6\%) and 10 children (55.5\%) respectively. The respondents in this study were mainly categorized in the range of severe hearing loss $(66.6 \%)$. Most of the respondents $(77.8 \%)$ belong to the type of sensorineural hearing loss (SNHL). Conclusion: Respondents with abnormal ABR results showed predominantly $(83.3 \%)$ had a hearing loss on both sides of the ear (bilateral). Pediatric patients with speech delay who underwent ABR testing mostly showed normal hearing. The majority of them were male, between 2-3 years of age.
\end{abstract}

Keywords: ABR (Auditory Brainstem Response), hearing loss, hearing test, speech delay

\begin{abstract}
ABSTRAK
Latar belakang: Keterlambatan bicara adalah salah satu penyebab gangguan perkembangan yang paling sering ditemukan pada anak. Keterlambatan bicara merupakan penyebab terbanyak pasien dikirim ke Unit Elektromedik. Tujuan: Untuk mengetahui profil hasil Brain Evoked Response Auditory (BERA) pada pasien anak dengan keterlambatan bicara di Klinik Elektromedik RSA UGM. Metode: Penelitian deskriptifobservasional dengan menggunakan data sekunder. Pengambilan sampel dilakukan dengan teknik total sampling pada periode 1 Januari 2019 sampai dengan 31 Desember 2019. Responden yang memenuhi kriteria inklusi dan eksklusi berjumlah 86 anak. Sebagian besar responden berada pada rentang umur $2-<3$ tahun $(45,3 \%)$ dan berjenis kelamin laki-laki $(68,6 \%)$. Hasil: Responden dengan hasil pemeriksaan BERA normal sejumlah 68 anak $(79,1 \%)$, sedangkan sisanya sebanyak 18 anak $(31,4 \%)$ tidak normal. Sebagian besar responden dengan hasil BERA normal berjenis kelamin laki-laki (42,6\%), sedangkan pada responden dengan hasil BERA tidak normal, sebagian besar berjenis kelamin perempuan (66,7\%). Responden dengan hasil BERA normal maupun tidak normal sebagian besar berada pada rentang umur $2-<3$ tahun, masing-masing berjumlah 29 anak (42,6\%) dan 10 anak $(55,5 \%)$. Sebagian besar responden pada penelitian ini tergolong pada gangguan pendengaran berat $(66,6 \%)$. Penelitian ini juga menunjukkan sebagian besar responden $(77,8 \%)$ termasuk dalam jenis gangguan pendengaran Sensorineural Hearing Loss (SNHL). Kesimpulan: Responden dengan hasil
\end{abstract}


BERA tidak normal ini menunjukkan sebagian besar (83,3\%) mengalami gangguan pendengaran pada kedua sisi telinga (bilateral).. Pasien anak dengan keterlambatan bicara yang dilakukan tes BERA sebagian besar hasilnya normal. Kebanyakan dari mereka berjenis kelamin laki-laki dan berusia 2-3 tahun.

Kata kunci: Keterlambatan bicara, gangguan pendengaran, pemeriksaan pendengaran, Auditory Brainstem Response (ABR), Brain Evoked Response Auditory (BERA)

Correspondence address: Mahatma Sotya Bawono, Departement of Otorhinolaryngology- Head Neck Surgery, Universitas Gadjah Mada Academic Hospital, Yogyakarta. Email: mahatmabawono@ugm.ac.id

\section{INTRODUCTION}

Speech delay is one of the most common causes of developmental disorders in children. The prevalence of language delay in Indonesia has not been widely studied. According to Judarwanto (2009), quoted by Sari et al. ${ }^{1}$ data on patients with speech delays at the Department of Medical Rehabilitation at Cipto Mangunkusumo Hospital in 2006 showed that from 1.125 visits of pediatric patients, $10.13 \%$ were diagnosed with speech and language delays.

Hearing is one of the most important human senses for speech and language development, communication, and learning. Hearing loss in children is an invisible disability that could bring non-optimal development and personal abilities. Based on data from the Basic Health Research (Riskesdas) conducted by the Health Research and Development Agency (Balitbangkes) of the Ministry of Health in 2018, the proportion of congenital hearing loss in infants aged 24-59 months in Indonesia was $0.11 \%$. $^{2}$

Early detection and appropriate treatment is the best option to optimize the critical period of hearing. ABR (Auditory Brainstem Response) is a simple, noninvasive, and objective test equipment for early identification of hearing impairment in children and neonates.

The Electromedical Unit of Universitas Gadjah Mada (UGM) Academic Hospital is a unit that has been officially opened since 2019. The data profile of pediatric patients who visited the Electromedical Unit were mostly children with special needs suspected of hearing loss. Speech delay is the most common reason for patients to come to Electromedical Unit. The available data were epidemiological data of the Academic Hospitals in Yogyakarta, which could illustrate thedistribution of ABR usage in the Electromedical Unit.

\section{METHOD}

This research was a descriptive observational study using consecutive sampling method from secondary data in the form of medical records and ABR (Auditory Brainstem Response) results. The population of this study was pediatric patients who had speech delays and underwent ABR examination at the Electromedical Clinic of UGM Academic Hospital from January 1, 2019 to December 31, 2019. The inclusion criteria in this study were pediatric patients aged 1-5 years who were diagnosed with delayed speech and had ABR examination results. The exclusion criteria were patients who had previously undergone ABR examination.

\section{RESULT}

The population of this study was 136 children, while those who met the criteria 
were 86 subjects. The gender distribution of respondents in this study was mostly 59 male children (68.6\%), while the rest were 27 female children (31.4\%). The age distribution of respondents could be seen in Table 1 .

The ABR results were interpreted as normal if a $\mathrm{V}$ wave appeared at an intensity of $30 \mathrm{~dB} \mathrm{nHL}$ on the ABR click examination and/or on a tone burst ABR examination. The study showed the results were normal with a percentage of $79.1 \%$, while ABR were not normal $20.9 \%$.

Respondents with normal ABR results were mostly male with $77.9 \%$. Meanwhile, respondents with abnormal ABR results were mostly female, which was $66.7 \%$. Respondents with normal and abnormal ABR results were mostly in the age range of $2-<3$ years old. The full distribution of ABR results based on the age of the respondents can be seen in the following Table 2.

Table 1. Age Distribution of Respondents

\begin{tabular}{ccc}
\hline Age range (years) & $\mathbf{n}$ & $\mathbf{\%}$ \\
\hline $1-<2$ & 27 & 31.4 \\
$2-<3$ & 39 & 45.3 \\
$3-<4$ & 16 & 18.6 \\
$4-<5$ & 4 & 4.7 \\
\hline Total & 86 & 100 \\
\hline
\end{tabular}

Table 2. Distribution of $A B R$ results by the age of respondents

\begin{tabular}{ccccc}
\hline $\begin{array}{c}\text { Age range } \\
\text { (years) }\end{array}$ & Normal ABR & \multicolumn{3}{c}{$\begin{array}{c}\text { Abnornal } \\
\text { ABR }\end{array}$} \\
\cline { 2 - 5 } & $\mathbf{n}$ & $\mathbf{\%}$ & $\mathbf{n}$ & $\mathbf{\%}$ \\
\hline $1-<2$ & 22 & 32.4 & 5 & 27.8 \\
$2-<3$ & 29 & 42.6 & 10 & 55.5 \\
$3-<4$ & 13 & 19.1 & 3 & 16.7 \\
$4-<5$ & 4 & 5.9 & 0 & 0 \\
\hline Total & 68 & 100 & 18 & 100 \\
\hline
\end{tabular}

The distribution of hearing loss in patients with abnormal ABR results could be seen in Table 3. Most of the patients with abnormal ABR results were in the range of profound hearing loss, which was $66.6 \%$. Based on the type of hearing loss, most of the respondents experienced Sensorineural Hearing Loss (SNHL), which was $77.8 \%$. Most of the respondents (83.3\%) experienced interference in both ears (bilateral).

The study obtained data on comorbid diagnoses in pediatric patients undergoing ABR examination, as shown in Table 4. From a total of 86 respondents, there were
52 children $(60 \%)$ with a diagnosis of speech delay without other comorbidities. There were $40 \%$ of children with speech delay who had comorbidities such as global developmental delay (14\%), cerebral palsy (7\%), autism spectrum disorder (ASD) (5\%), Down syndrome (5\%), epilepsy (5\%), and microcephaly (2\%). Abnormalities of ABR results were found mostly in patients with Down's syndrome, microcephaly, and cerebral palsy. There was no abnormality in ABR results in children with speech delay in patients with global developmental delay, autism, epilepsy, and attention deficit hyperactivity disorder (ADHD). 
Table 3. Distribution of hearing loss

\begin{tabular}{llc}
\hline & $\mathbf{n}$ & $\mathbf{\%}$ \\
\hline Hearing loss range & & \\
Mild & 2 & 11.1 \\
Moderate & 1 & 5.6 \\
Moderately severe & 1 & 5.6 \\
Severe & 2 & 11.1 \\
Profound & 12 & 66.6 \\
\hline Total & 18 & 100 \\
\hline Types of hearing loss ${ }^{4}$ & & \\
CHL & 3 & 16.7 \\
SNHL & 14 & 77.8 \\
MHL & 1 & 5.5 \\
\hline Total & 18 & 100 \\
\hline The side of the ear that has & & \\
hearing loss & & \\
Unilateral & 3 & 16.7 \\
Bilateral & 33.3 \\
\hline Total & 3 & 100 \\
\hline
\end{tabular}

Table 4. Distribution of ABR results based on concomitant diagnosis

\begin{tabular}{lccc}
\hline Concomitant diagnosis of speech delay & $\begin{array}{c}\text { Normal } \\
\text { ABR (n) }\end{array}$ & $\begin{array}{c}\text { Abnormal ABR } \\
\text { (n) }\end{array}$ & Total (n(\%)) \\
\hline $\begin{array}{l}\text { Global } \\
\text { developmental delay }\end{array}$ & 12 & 0 & $12(14)$ \\
$\begin{array}{l}\text { Autism spectrum } \\
\text { disorder }\end{array}$ & 4 & 0 & $4(5)$ \\
$\begin{array}{l}\text { Down's } \\
\text { Syndrome }\end{array}$ & 2 & 2 & $4(5)$ \\
Cerebral palsy & 6 & 0 & $6(7)$ \\
$\begin{array}{l}\text { Epilepsy } \\
\text { Attention- deficit/hyperactivity disorder } \\
\text { (ADHD) }\end{array}$ & 2 & 0 & $4(5)$ \\
Microcephaly & 1 & 0 & $2(2)$ \\
Speech delay without cormobid & 37 & 1 & $2(2)$ \\
\hline Total & 68 & 15 & $52(60)$ \\
\hline
\end{tabular}




\section{DISCUSSION}

The total number of patients who underwent ABR examination was 136 children. Out of 136 children, 86 subjects met the inclusion and exclusion criteria to become research respondents. Of these 86 respondents, most of them were aged $2-<3$ years. There were 59 male children $(68.6 \%)$.

These results were in line with Gunawan et al. ${ }^{5}$ research on the Profile of Patients with Speech Delay with ASSR Examination at Taman Observasi Anak (TOA) Jala Puspa Rumkital Dr. Ramelan Surabaya in 20162017. The research showed that the average age of subjects with speech delays was 2.65 years (in respondents with minimum age of 1 year and maximum age of 5 years), and most patients were male.

The same result was also shown by Wijana et al. ${ }^{6}$ (2014), on children under 5 years old who underwent hearing assessment in Hasan Sadikin Hospital Bandung in December 2008 - June 2011, which had shown that the number of male sample (119) were higher than female sample (79).

A research conducted by Aditomo et.al. ${ }^{7}$ also showed similar result. Based on ages and gender, patient which underwent ABR test from January- December 2016 in Kariadi General Hospital Semarang, were mostly around $0-3$ years old $(58.6 \%)$ and also male $(59.1 \%)$.

In our study, abnormal ABR results were found in 18 respondents. Out of these 18 respondents, most of them were 12 female children $(66.7 \%)$. This result was different from previous research conducted by Sari et al. ${ }^{1}$ which reported children with speech delays of hearing loss were 298 male with a percentage of $65.9 \%$.

In our study, based on their hearing range, most respondents experienced profound hearing loss as many as 12 children $(66.6 \%)$. It was in line with results of Sari et al. ${ }^{1}$ that most children with speech delay underwent hearing examinations in the Neurotology Section of IKTHT-KL RSUP Dr. Moh. Hoesin had severe perceptive deafness. Furthermore, they stated that the most severe degree of perceptive deafness in the right ear was $43.6 \%$ (197 children), while the left ear had the most moderate degree of 50\% (226 children).

The same results were also obtained by the study of Gunawan et al. ${ }^{5}$ which showed that most of the patients with speech delay with ASSR examination had abnormal examination results as profound hearing loss. Another research by Aditomo et al. ${ }^{7}$, Wijana et al. ${ }^{8}$ and Purnami $^{9}$ showed that ABR result o $n$ hearing loss cases were mostly profound. Result from those research consecutively were $44.07 \%, 45 \%$, and $87.27 \%$.

In our research, based on the type of hearing loss, most of the respondents who experienced sensorineural hearing loss (SNHL) were 14 children $(77.8 \%)$. While patients who experienced conductive hearing loss (CHL) were 3 children (16.7\%) and only 1 child $(5.5 \%)$ experienced mixed hearing loss (MHL).

Dewi et al. ${ }^{10}$ conducted a study on the characteristics of congenital SNHL in 624 children with speech delays. Subjects were tested with Auditory Brainstem Response (ABR). They found 270 children with normal hearing and 354 children with hearing loss, out of which there were 286 bilateral congenital SNHL and 17 congenital CHL cases.

Hearing impairment in children, especially SNHL, will impair speech and language development and require good management. According to Soepardi et al. and Smeltzer et al. quoted by Jauhari, ${ }^{11}$ sensorineural hearing loss (SNHL) was caused by impairment in the inner ear or brainstem pathway. This could hinder the learning process to talk and the the ability to communicate. Mostly this kind of impairment could not be cured because the damage was 
permanent. Management on children with SNHL is based on early detection and early intervention. Primary intervention at present is with hearing aid and cochlear implantation. Mitigation for children with SNHL focuses on vaccination and health education program. ${ }^{11,12}$

Conductive hearing loss (CHL) is an impairment that caused by a problem in outer or middle ear pathway, which disrupts the soundwave to enter the inner ear. This impairment will decrease the sound wave volume level which enter the inner ear, thus it does not cause distortion nor disruption to the sound clarity that being received. Mostly, this type of impairment can be treated with medication. The third type of hearing impairment is mixed hearing loss (MHL), which is a combination of CHL and SNHL. ${ }^{11}$

Based on the side of the ear with hearing loss, our study found 15 respondents $(83.35 \%)$ had bilateral and 3 respondents $(16.7 \%)$ had unilateral ear impairments. This result was more or less the same with what Sari et al. ${ }^{1}$ found in their research. She found that the results of bilateral types of deafness were more than unilateral deafness, 365 children $(80.8 \%)$ had bilateral deafness, while 87 children $(19.2 \%)$ had unilateral deafness. Wijana et al.8 and Purnami et al. ${ }^{9}$ also concurred with this and stated that most children who underwent hearing assessment had bilateral hearing impairment.

Observing the normal and abnormal ABR results showed that speech delay children with hearing loss and without hearing loss were mostly aged $2-<3$ years. Respondents who experienced speech delay without hearing loss were mostly male, while respondents who experienced speech delay with hearing impairment were mostly female. The result was different with the research conducted by Sari et al. ${ }^{1}$ which found more male respondents with speech delays with hearing impairment as many as 298 children (65.9\%).

All of the children who underwent the ABR examination were speech delay patients. Most comorbid diagnoses were global developmental delay (14\%), cerebral palsy (7\%), autism spectrum disorder (5\%), Down's syndrome (5\%), epilepsy $(5 \%)$, ADHD (2\%), and microcephaly ( $2 \%)$. Interestingly, only a small proportion of children with speech delays were accompanied by abnormal ABR results (22\%). Children with other comorbidities such as autism and ADHD were not found to have abnormal ABR results. On the other hand, abnormal ABR results were found in speech-delayed children with accompanying diagnoses of cerebral palsy, Down syndrome, and microcephaly.

Predisposing factors which leads to babies and children hearing impairment are: prematurity, history of hospitalization in Intensive Care Unit, mother with TORCH infection during pregnancies, hyperbilirubinemia, facial anatomical defect, history of ototoxic drugs administration, congenital meningitis, and low/very low birth weight. ${ }^{13,14}$

Early detection and appropriate treatment is the best option to optimize the critical period of hearing. Early detection of language delay could be performed using hearing screening tools or with specific hearing diagnostic tools. ABR (Auditory Brainstem Response) is an easy, non-invasive, and objective test tool for early identification of hearing impairment in children and neonates. It couldbe used for screening infants and patients with trouble hearing. All of it could be conducted in Pediatric Section of UGM Academic Hospital.

Early detection and appropriate treatment is the best option to optimize the critical period of hearing. Early detection of language delay could be achieved by using hearing screening tools or by specific hearing diagnostic tools. ABR (Auditory Brainstem Response) is an easy, non-invasive, and objective test tool for early identification of hearing impairment in children and neonates. It could be used for 
screening infants and patients with hearing trouble. All detection of hearing impairment could be conducted in Pediatric Section of UGM Academic Hospital.

Our study found out of 86 subjects with speech delay, there were $68(79.1 \%)$ had normal and 18 (31.4\%) had abnormal results of $A B R$ examination. Out of subjects with abnormal ABR, there were 12 children $(66.6 \%)$ with profound hearing loss, 14 children (77.8\%) with SNHL type hearing impairment, and 15 children (83.3\%) had bilateral hearing loss.

\section{REFERENCE}

1. Sari SNL, Memy YD, Ghanie A. Angka Kejadian Delayed Speech Disertai Gangguan Pendengaran pada Anak yang Menjalani Pemeriksaan Pendengaran di Bagian Neurootologi IKTHT-KL RSUP Dr. Moh. Hoesin. Jurnal Kedokteran dan Kesehatan. 2015;2(1):121-7.

2. Kementerian Kesehatan RI. Infodatin, Pusat Data dan Informasi Kementerian Kesehatan RI: Disabilitas Rungu.2019. Available from: https://pusdatin.kemkes.go.id/resources/ dow nload/pusdatin/infodatin/infodatintunarungu-2019.pdf. [last retrivied on 2020 May 15]

3. Stach BA. Clinical Audiology: An Introduction, Second Edition. USA: Delmar. 2010. p.119-21

4. Northen JL, Downs MP. Hearing in Children Sixt Edition. USA: Plural Publishing. 2014. p.20-3.

5. Gunawan, YE, Poerwantiningrum, PE. Profil Penderita Keterlambatan Bicara dengan Pemeriksaan ASSR di TOA Jala Puspa Rumiktal dr. Ramelan Surabaya. Hang Tuah Medical Journal. 2019;16(2):161-70.

6. Wijana, Syamsuddin A, DewiYA. Gelombang Auditory Brainstem Response (ABR) pada Anak Dibawah Lima Tahun. Majalah Kedokteran Bandung. 2014;6(3):183-8.

7. Aditomo R, Ruspita, DA. Karakteristik Pasien yang Menjalani Pemeriksaan Brain Evoked Response Audiometry (BERA) di RSUP Dr. Kariadi Semarang. CoMPHI. 2021;2 (1):132-8.
8. Wijana, Ulfa A.ABR profile in children with congenital rubella syndrome at Hasan Sadikin General Hospital.ORLI.2019;49(1):29-34.

9. Purnami N, Dipta C, Rahman MA.Characteristic of infant and young children with sensorineural hearing loss in Dr Soetomo Hospital.ORLI.2018; 48(1): 12- 7.

10. Dewi YA \& Agustian RA. Karakteristik Gangguan Dengar Sensorineural Kongenital pada Anak yang dideteksi dengan Brain Evoked Response Audiometry. Majalah Kedokteran Bandung. 2011;43(2):77-82.

11. Jauhari. Deteksi Gangguan Pendengaran pada Anak Usia Dini. Genius. 2020;1(1):6171.

12. Novastuti, CD \& Wiyadi, HMS. Sensorineural Hearing Loss pada Anak. Jurnal THT-KL. 2016;9(3):118-25.

13. Azwar. Deteksi Dini Gangguan Pendengaran pada Anak. Jurnal Kedokteran Syah Kuala. 2013;13(1):59-64.

14. Rahayuningrum DF, Naftali Z, YusmawanW. Faktor-faktor Risiko yang Berpengaruh Terhadap Sensorineural Hearing Loss (SNHL) Pada Penderita Speech Delay: Studi di Rumah Sakit Umum Pusat Dokter Kariadi Semarang. Jurnal Kedokteeran Diponegoro. 2016;5(4): 649-57. 